\title{
LCA and economic evaluation of landfill leachate and gas technologies
}

Damgaard, Anders; Manfredi, Simone; Merrild, Hanna Kristina; Stensøe, Steen; Christensen, Thomas Højlund

Published in:

Waste Management

Link to article, DOI:

10.1016/j.wasman.2011.02.027

Publication date:

2011

Link back to DTU Orbit

Citation $(A P A)$ :

Damgaard, A., Manfredi, S., Merrild, H. K., Stensøe, S., \& Christensen, T. H. (2011). LCA and economic evaluation of landfill leachate and gas technologies. Waste Management, 31(7), 1532-1541.

https://doi.org/10.1016/j.wasman.2011.02.027

\section{General rights}

Copyright and moral rights for the publications made accessible in the public portal are retained by the authors and/or other copyright owners and it is a condition of accessing publications that users recognise and abide by the legal requirements associated with these rights.

- Users may download and print one copy of any publication from the public portal for the purpose of private study or research.

- You may not further distribute the material or use it for any profit-making activity or commercial gain

- You may freely distribute the URL identifying the publication in the public portal

If you believe that this document breaches copyright please contact us providing details, and we will remove access to the work immediately and investigate your claim 


\title{
LCA and economic evaluation of landfill leachate and gas technologies
}

\author{
Anders Damgaard ${ }^{\mathrm{a}} *$, Simone Manfredi ${ }^{\mathrm{a} 1}$, Hanna Merrild ${ }^{\mathrm{a} 2}$, \\ Steen Stensøe ${ }^{\mathrm{b}}$ \& Thomas H. Christensen ${ }^{\mathrm{a}}$ \\ ${ }^{\mathrm{a}}$ Department of Environmental Engineering \\ Technical University of Denmark \\ Miljoevej, Building 113, DK-2800 Kongens Lyngby \\ Denmark \\ ${ }^{\mathrm{b}} \mathrm{COWI}$ \\ Parallelvej 2, DK-2800 Kongens Lyngby \\ Denmark
}

${ }^{1}$ European Commission - Joint Research Centre (JRC), Via Enrico Fermi 2749; Building 27, Office 035; T.P. 270; I-21027 Ispra (VA), Italy

${ }^{2}$ FORCE Technology, Hjortekærsvej 99, 2800 Kgs. Lyngby, Denmark 


\section{Abstract}

Landfills receiving a mix of waste, including organics, have developed dramatically over the last 3-4 decades; from open dumps to engineered facilities with extensive controls on leachate and gas. The conventional municipal landfill will in most climates produce a highly contaminated leachate and a significant amount of landfill gas. Leachate controls may include bottom liners and leachate collection systems as well as leachate treatment prior to discharge to surface water. Gas controls may include oxidizing top covers, gas collection systems with flares or gas utilization systems for production of electricity and heat.

The importance of leachate and gas control measures in reducing the overall environmental impact from a conventional landfill was assessed by life-cycle-assessment (LCA). The direct cost for the measures were also estimated providing a basis for assessing which measures are the most cost-effective in reducing the impact from a conventional landfill. This was done by modeling landfills ranging from a simple open dump to highly engineered conventional landfills with energy recovery in form of heat or electricity. The modeling was done in the waste LCA model EASEWASTE. The results showed drastic improvements for most impact categories. Global warming went from an impact of 0.1 person equivalent (PE) for the dump to - $0.05 \mathrm{PE}$ for the best design. These correspond to a load of $870 \mathrm{~kg} \mathrm{CO}_{2}$-equivalents per tonne of waste landfilled (on a wet weight basis) to a saving of $-435 \mathrm{~kg} \mathrm{CO}$-equivalents per tonne of waste landfilled, respectively. Similar improvements were found for photochemical ozone formation (0.02 PE to $0.002 \mathrm{PE}$ ) and stratospheric ozone formation (0.04 PE to 0.001 PE).

For the toxic and spoiled groundwater impact categories the trend is not as clear. The reason for this was that the load to the environment shifted as more technologies were used. For the dump landfill the main impacts were impacts for spoiled groundwater due to lack of leachate collection, 2.3 PE down to 0.4 PE when leachate is collected. However, at the same time, leachate collection causes a slight increase in eco-toxicity and human toxicity via water $(0.007 \mathrm{E}$ to $0.013 \mathrm{PE}$ and 0.002 to $0.003 \mathrm{PE}$ respectively). The reason for this is that even if the leachate is treated, slight amounts of contaminants are released through emissions of treated wastewater to surface waters. The drop in the impact from potentially spoiled groundwater, due to increased collection of leachate, is offset by a rise in increased human and eco-toxicity via water, due to contaminants in the larger amount of treated waste water.

The largest environmental improvement with regard to the direct cost of the landfill was the capping and leachate treatment system. The capping, though very cheap to establish, gave a huge benefit in lowered impacts, the leachate collection system though expensive gave large benefits as well. The other gas measures were found to give further improvements, for a minor increase in cost.

Keywords: EASEWASTE, LCA, landfill, leachate and gas collection 


\section{Introduction}

Landfills have developed dramatically over the last 3-4 decades; from open dumps to engineered facilities with extensive controls on leachate and gas. Albeit many countries have detailed guidelines on how to plan, design and operate landfills, landfills will also in the future on a global scale encompass a wide range of technologies with various potential impacts on the environment. Due to regulations conventional landfills as presented here are being outfaced in a European context as organic waste is being treated with other technologies, but it is still the dominant technology worldwide both in industrialized and developing countries.

The conventional municipal landfill will in most climates produce a highly contaminated leachate and a significant amount of landfill gas. Leachate controls may include bottom liners and leachate collection systems as well as leachate treatment prior to discharge to surface water. Gas controls may include oxidizing top covers, gas collection systems, flares and also gas utilization in terms of electricity and heat production. These technical controls have also increased the direct cost of landfilling, which in some cases may be as high as 150 Euro per tonne (Hogg, 2002).

The purpose of this paper is to asses by life-cycle-assessment (LCA) how important leachate and gas control measures are in reducing the overall environmental impact from a conventional landfill. The direct cost for the measures are also estimated providing a basis for assessing which measures are the most cost-effective in reducing the impact from a conventional landfill. The environmental benefits of introducing new landfill technologies such as the bioreactor, the flushing bioreactor and the semi-aerobic landfill technology are not addressed here but in a paper by Manfredi \& Christensen (2009).

\section{Life-Cycle-Assessment: Approach and model}

LCA provides a consistent framework for assessing potential environmental impacts for a specified system including any related up-stream and down-stream processes. We have chosen to use the EASEWASTE model (Kirkeby et al., 2006) for modeling the environmental impacts from landfilling. The EASEWASTE landfill module is described in detail by Kirkeby et al. (2007).

The functional unit for the study is 1 tonne of wet household waste deposited in a landfill with an average depth of $12.5 \mathrm{~m}$ and a compacted density of $800 \mathrm{~kg} / \mathrm{m}^{3}$; all the environmental aspects are accounted for in a time horizon of 100 years after disposal. The depth and density is used to calculate the amount of leachate generation based on the surface associated with this 1 tonne in the overall landfill design. These numbers are used to calculate the amounts of gas and leachate as explained later.

Table 1 presents the impact categories that EASEWASTE uses for aggregating all the quantified emissions to air, soil, surface water and groundwater. Most of the impact categories are based on the EDIP 97 method (Wenzel et al., 1997). Table 1 also presents the normalization references used to convert the individual potential impacts into person equivalents (PE), which is an average value for the yearly contribution to a given impact category by all the activities and consumptions relative to one person. In the article the potential impacts are divided into 3 groups: standard, toxicity related and spoiled groundwater (i.e. groundwater polluted above the drinking water criteria).

\subsection{Standard potential impacts}

The standard potential impacts include Global Warming (GW), Photo-chemical Ozone Formation (POF), Ozone Depletion (OD), Acidification (AC) and Nutrient Enrichment (NE). The 
methodologies utilized for the assessment of these environmental impacts are well-

128 acknowledged, although different units may appear in different models. The degree of certainty

129 of the potential impacts can be considered high. In the case of global warming, emissions of $\mathrm{CO}_{2}$

130 of biological origin are considered neutral as discussed in Christensen et al. (2009). This means that the $\mathrm{CO}_{2}$ being emitted from the landfill as well as methane that is oxidized into $\mathrm{CO}_{2}$ are counted as neutral and not contributing to GW since it originates from organic matter generated by an equivalent uptake of $\mathrm{CO}_{2}$ during the plant growth. Emissions of $\mathrm{CO}_{2}$ originating from fossil sources will be counted as contributing to GW, since this release of carbon is not balanced by a recent, equivalent uptake of carbon. The EASEWASTE model also counts the amount of biogenic carbon entering the landfill and left after the time horizon of the study (as default in EASEWASTE set to 100 years). This carbon is considered sequestered in the landfill and will therefore be counted as a saving and thereby decreasing the potential GW impact. The amount of biogenic CO2 released from the landfill is being calculated in the EASEWASTE inventory, it is only in the characterization that it is counted as neutral. It is important to note that the neutrality associated with biogenic $\mathrm{CO}_{2}$ is only methodologically correct when factoring in carbon sequestration as discussed in Christensen et al. (2009). Alternatively the biogenic $\mathrm{CO}_{2}$ could have been included with an impact, but in this case carbon sequestration should not have been included in order to be methodologically consistent.

\subsection{Toxicity-related potential impacts}

Toxicity-related potential impacts include Human Toxicity in soil (HTs), water (HTw) and air (HTa) as well as Ecotoxicity in soil (ETs) and in water (ETw). The degree of certainty of the impact potentials calculated for this group is low since the utilized methodology is still being developed and tested. Furthermore the model can calculate the stored toxicity in the landfill. This is an impact that has been introduced in EASEWASTE (adapted from Hansen et al. 2004 and Hauschild et al. 2008). The model calculates the amount of each toxic substance (heavy metals) that entered the landfill and is left at the end of the time horizon of the study, and ascribes each substance the characterization factor for eco-toxicity to soil and water. In this study it was decided to leave out the graphs for these impacts; this is not to say that these are not important, but because the same amount of toxic substance entered each landfill and it is almost the same amount that is left after the time horizon of the study, the results would be the same for all landfill. Conversely, if the study had included diversion of waste streams from the landfill this would have been extremely important.

\subsection{Groundwater impact}

Impact on groundwater is usually not addressed in LCA, but is here represented by Spoiled Groundwater Resource (SGWR). The impact is calculated as the volume of groundwater that the input to the groundwater (here leachate) can contaminate up to the drinking water criteria. This impact is adapted after Birgisdóttir et al. (2007) where it was used on leaching from bottom ash residues used in road construction. In the present study the WHO (2006) drinking water criteria were used instead of the Danish drinking water criteria used in Birgisdóttir et al. (2007). Similarly as for the other impact categories, the calculation is done for each substance and the sum yields the potential impact. The impact is normalized with regards to the amount of contaminated groundwater per person per year in Denmark ( $2900 \mathrm{~m}^{3} /$ person/year (DMU \& DJF, 2003)); the normalization reference is based on the contamination by nitrate and chloride, and 
must be seen as a rough indicator. In previous studies with EASEWASTE*,* a normalization reference of $140 \mathrm{~m}^{3} /$ person/year was used which was the amount of drinking water consumption per person per year. That should be kept in mind when comparing with previous studies. The Spoiled Groundwater Resource impact potential is relevant only when groundwater is considered a limited resource and utilized.

\section{The conventional landfill - modeling and design}

\subsection{Landfill types}

The different landfill designs have been divided into 3 archetypes under which there are a couple of alternatives, giving a total of 7 different scenarios. The 3 archetypes are described briefly and an overview is presented of some of the most important technical differences for each landfill, for more detailed info section 3.3 contains the precise data used for each scenario.

\section{The dump}

The dump is considered in terms of an Open dump since this represents the theoretical worst case of a landfill with no measures to control leachate or gas. Besides the emissions from leachate and gas, the main environmental load comes from the diesel combusted in the specialized vehicles operating on-site (compactors, dozers, etc). The diesel consumption is estimated to $0.8 \mathrm{~L}$ diesel per tonne of waste (as cumulative value throughout 100 years).

Also a Covered dump is considered; this is a dump that is supplied with a low quality soil cover and vegetation after filling of the landfill section. This results in a reduced leachate generation since the soil cover can hold some water for evapotranspiration from the wet period to the dry period of the year. The top cover also provides some gas oxidation in particular when the gas generation is modest in the later part of the 100 year period considered. The diesel consumption is here estimated to $0.9 \mathrm{~L}$ diesel per tonne of waste for waste compaction, soil moving and for establishing the top cover. It is assumed that the soil for the cover is present at the site.

\section{The simple conventional landfill}

The simple conventional landfill has introduced a bottom liner, leachate collection and leachate treatment. The top cover is of higher quality than for the covered dump and therefore it is able to provide a superior oxidation of gas constituents. The gas may migrate through the top cover or be collected and managed by biofilters or by flares. The biofilters are only partially effective while the flare is highly effective in oxidizing the gas. However, the flare produces some secondary air pollutants (NSCA, 2002). The diesel consumption is here set to $2 \mathrm{~L}$ diesel per tonne of waste, used for waste compaction, soil moving, establishing the top cover, installing leachate and gas collection systems and for post-closure operations. The collected fraction of leachate is sent to a treatment plant, the pollutants remaining in the treated leachate is assumed discharged to surface water, while the uncollected fraction is assumed to reach the groundwater.

\section{The energy-recovery conventional landfill}

The energy-recovery conventional landfill represents the most advanced conventional landfill, where the gas is collected and used for energy production. The design is similar to the simple conventional landfill, but the collected gas is here used for energy production. The produced energy is assumed to substitute $100 \%$ for energy production at a coal-fired power plant or a 
power plant based on natural gas, either in pure power production or as combined heat and power (CHP). The saved emissions from the power plants are credited the landfill gas utilization system.

218 The reason to choose to model both coal and natural gas substitution is that it is found that this can often have a large impact in the life cycle assessment of waste management (Fruergaard et al., 2009).

\subsection{Basic features}

The EASEWASTE model contains a flexible landfill module as described by Kirkeby et al. (2007).. It is assumed that the landfill cell is being filled within 2 years after which it is closed and leachate and gas mitigation systems are installed in relevant scenarios. The annual net infiltration for the vegetated top cover is set to $300 \mathrm{~mm}$.

Energy used for operation and maintenance and excavation of the landfill is included for all the landfills and considered to be identical. Emissions associated with these operations as well as upstream production are accounted for as well.

The landfill is considered for a 100 year period. All uses of resources and all emissions during this period are accounted for. It is likely that landfill gas generation is approaching a negligible value within this period. The waste being landfilled is assumed to be municipal solid waste with a wet weight composition of 35\% organics (food waste, flowers etc.), 30\% paper and cardboard, $10 \%$ plastics, $9 \%$ glass and $16 \%$ of other fractions. The total amount of methane generated during the 100 years is calculated to $77 \mathrm{Nm}^{3} \mathrm{CH}_{4}$ per tonne of wet waste corresponding to approximately $160 \mathrm{Nm}^{3}$ landfill gas (LFG) per tonne of wet waste for this waste composition. Contaminated leachate, however, is expected to appear also after 100 year. However, this circumstance is not accounted for in the assessment. If the composition of waste sent to the landfill were to change, this would directly impact the amount of generated methane and thereby the performance of the landfill.

The development in leachate and gas composition and amount over the 100 year period is described by defining typical values for 4 time segments within the 100 year period. The values used in this study are shown in Table 2 and 3.

Table 2 shows the composition of the landfill gas through the 4 defined time periods; average oxidation removal efficiencies relative to each period are also provided. Oxidation implies that the substance is converted to a non-impacting substance. The composition is primarily based on Deipser et al. (1996), Mahieu et al. (2005), NSCA (2002), Rettenberger (2005), Rettenberger and Stegmann (1996), Scheutz et al. (2004), Scheutz and Kjeldsen (2005). Table 3 gives the concentration of modeled compounds in the leachate composition. The composition is assumed to be the same for all the different scenarios, even though there are some variations in infiltration rates. However, it is assumed that the controlling parameters for the leachate formation are comparable in all landfills. Removal efficiencies are here defined as the amount of substance that can be removed in the leachate treatment plant, and therefore does not end up being released into a freshwater source. The composition is mainly based on data from Ehrig (1983), Kjeldsen and Christophersen (2001), Lee and Jones (1993), Reinhart et al. (1998). Removal efficiencies are based on Knox et al. (2003), U.S. EPA (1989 and 1992)

The values in Table 2 and 3 are typical values aggregated from many different sources. These data are the same for all the modeled landfills, and the only difference is the amount of produced leachate and gas multiplied with these generation values. 


\subsection{Technical measures}

The technical measures of the conventional landfill relates primarily to leachate and gas control.

Table 4 describes the technical measures applied in each scenario. The performance of these measures, including any functional deterioration over time, is also described by constant parameters within each of 4 time segments. The length of the segments can in EASEWASTE be defined independently for each measure.

Typical or possible measures regarding leachate and gas controls are described below. These are combined to define the various conventional landfills representing different level of environmental protection. The key parameter values are presented in Table 5.

\section{Measures for landfill gas control}

- Gas measure 1 (G1): No top cover and no gas collection system are installed. All the generated gas is emitted directly to air. No oxidation of the landfill gas is thus expected to take place. (Open dump)

- Gas measure 2 (G2): A soil top cover is installed after the filling of the cell (2 years) and provides partial oxidation of the various constituents of the gas. The oxidation of methane is assumed to be low during the first 40 years where the flow rate through the top cover is high (an average of $35 \%$ is oxidized), and high at the later time segments (around $80 \%$ is oxidized) when the flow rate is modest. The oxidation rates used are based on numbers from a review by Chanton et al. (2009).(Covered dump)

- Gas measure 3 (G3): A gas collection system is installed after the cell has been filled with waste (2 years). Efficiencies of gas collection systems are widely discussed. Based on a study by Börjesson et al. (2009) a rate of 75\% LFG collection assuming best available technology performance was decided. This gives an overall gas extraction of $58 \mathrm{~m}^{3} \mathrm{CH}_{4}$ per tonne of landfilled wet municipal waste. The collected fraction is treated at the site, either by biological filters (G3A), which on average oxidizes $60 \%$ (based on Gebert (2003) and Scheutz (2002)) of the methane without forming any secondary gaseous products except $\mathrm{CO}_{2}$, or in flares (G3B), which oxidize 98-99.7\% of the methane, while some secondary gaseous products are being formed (NOx, CO, dioxin etc.). Data for emissions from flares are based on NSCA (2002) and U.S. EPA. (2000, 2008). The uncollected fraction of the LFG is partly oxidized in the top soil cover, and it is assumed that $80 \%$ is oxidized in the period where there is gas collection, resulting in a low flow. The oxidation rates in the last 60 years where there is no gas collection were lowered. This is due to the assumption that fugitive gas releases through leachate and gas collection systems may take place, which would lower the overall oxidation efficiency even though the flow is lower here. (Conventional landfill)

- Gas measure 4 (G4): Similar to Gas Measure 3. The collected fraction of gas is here sent to a facility producing either electricity at an efficiency of 30\% (G4E) or heat at an efficiency of $80 \%$ (G4H). Data for emissions from boilers and combustion engines are based on NSCA (2002) and U.S. EPA. (2000, 2008). The produced energy is assumed to substitute $100 \%$ for energy production at a coal-fired power plant (G4EC and G4HC) or power plant based on natural gas (G4EN and G4HN). The saved emissions from the power plants are credited the landfill gas utilization system. Electricity consumption is assumed generated by the same process as for the avoided electricity. (Conventional energy recovery landfill). 
Measures for landfill leachate control

- Leachate measure 1 (L1): No bottom liner and no leachate collection system are installed. The generated leachate migrates directly into the groundwater. (Open and covered dumps)

- Leachate measure 2 (L2): Bottom liner and leachate collection system are installed (done in combination with G2-4 where the landfill is capped which also leads to a lower leachate production). The efficiency of the leachate collection system is high during the first 20 years (95\%), assumed to fall to $80 \%$ after 20 years where there starts to be some liner failure and clogging, and finally down to $60 \%$ in the aftercare period. This is a conservative estimate; the liner might be lasting much longer. The collected fraction of the generated leachate is treated prior to discharge to surface water (marine or fresh). The removal efficiencies of the various leachate constituents are based on a range of values for each constituent(s)*remove $\mathrm{s}^{*}$ and has been recalculated to mean values, these give efficiencies ranging from $22 \%$ (for phosphate) and up to 97-98\% (for BOD and ammonia). Emissions from sludge management are disregarded, and it is acknowledged this can be an issue due to the high amount of contaminants in the sludge. The uncollected fraction of the generated leachate is assumed to reach the groundwater.

\section{The conventional landfill: Cost estimates of technical measures}

Landfill costs are highly variable. Hogg (2002) reports that even within Europe the cost may range from 25 to 150 Euro/tonne excluding landfill taxes. This variation is partially due to different levels of technical measures installed at the landfill and partially due to regional differences in the cost of land, wages and earnings from sale of energy from LFG. In reality, the price (i.e. the gate fee) of landfilling may not directly reflect the actual cost, but merely be controlled by the market and availability of alternatives to the actual landfill.

Table 6 presents our estimated typical unit cost for the technical measures described above (based on: Bates and Haworth, 2001; Delaware Solid Waste Authority, 2006; Hogg, 2002; Johannessen, 1999a, 1999b; Purdy and Shedden, 2005). The baseline cost for a dump without any measures to control leachate or gas is set to 40 Euro/tonne, including capital costs and operational costs. This baseline cost is used for all the landfills and in addition the costs for the technical measures are added step by step.

The unit costs are used to evaluate the cost-effectiveness of the different measures in relation to the environmental benefits that are achieved. The hypothesis is that some measures might give a high environmental benefit but at a high cost, while other measures can achieve similar benefits at a much lower cost.

The cost components are combined differently for the seven landfill scenarios. All of the landfills have the same baseline cost which includes land acquisition, construction and landfill operation. Most of the numbers used for the calculations are given in Euro/tonne and can simply be introduced into the "per tonne" calculations. However, the gas collection, leachate collection and treatment, electricity and district heating production were given in other units and therefore have been calculated into Euro/tonne. This has been done with the data from the life cycle assessment inventory, and these amounts are given in the table footnotes. The total costs for the different landfill technologies, can be seen at the bottom of Table 6. Additionally uncertainty in the allocated numbers are presented in Table 6, and this accumulated uncertainty are shown in Figure 3. 


\section{Results and discussion}

349

350

351

352

353

354

355

356

357

358

359

360

361

362

363

364

365

366

367

368

369

370

371

372

373

374

375

376

377

378

379

380

381

382

383

384

385

386

387

388

389

\subsection{Standard impact categories}

Through the use of the LCA model EASEWASTE significant aspects of landfill design have been modeled and associated potential environmental impacts have been estimated. The main results achieved are given in Figures 1, 2 and 3.

Figure 1 gives the normalized impact potentials for the ordinary impact categories. It can be seen that global warming is significant in the dump landfills and in the landfill with the simple soil cover (up to $0.1 \mathrm{PE}$ per tonne wet waste corresponding to $870 \mathrm{~kg} \mathrm{CO}_{2}$-equivalents per tonne wet waste). When a gas collection system is installed, some oxidation of the gas constituent can be provided by biofilters. These do not generate any other new emissions besides carbon dioxide (biogenic). Flares provide a much more efficient reduction of methane emissions, so that the global warming impact is lowered to - $0.026 \mathrm{PE}$ per tonne wet waste. The reason for the negative number is due to the fact that carbon sequestration is included in the number for all the landfill ( $0.05 \mathrm{PE}$ sequestered per tonne wet waste). This sequestration is calculated based on the biogenic carbon content, which is still present in the landfill after the timeframe of the study (100 years). This carbon content in based on the defined waste composition sent to the landfill. The importance of this is illustrated by the "Net value - no sequestration" marks in Figure 1 where the sequestration has been excluded. If the time horizon for the study was further extended the amount of sequestered carbon would drop a little as a certain fraction of the remaining carbon would be released (the last $4 \%$ of easily degradable carbon which is not released in the first 100 years where $96 \%$ is assumed released), but an amount of the carbon is also expected to be stored in sequestered form in the future. When the collected gas is sent to an energy recovery facility, the global warming savings are further increased, as shown in Figure 1. It can here also be seen that the savings calculated when substituting coal are higher than that with natural gas. This shows that it is important to evaluate what energy source would have been used if the energy had not been recovered from the landfill.

The impact potentials calculated for the other ordinary impact categories are smaller in magnitude than the impact potential estimated for global warming. The impact for photochemical ozone formation is mainly due to emissions of methane and VOC's, which follows the same declining trend as for global warming due to the mitigation measures for these substances. Impact potentials for acidification and nutrient enrichment are very close to zero PE, and the main substances of importance here, is the leaching of phosphate and ammonia to surface water (marine or fresh). Stratospheric ozone depletion is the second largest impact with an impact of up to 0.04 PE per tonne of wet waste. This is due to emissions of CFC11 and CFC12 and their degradation products. Even though a large part of these are oxidized in the landfills as discussed by Scheutz and Kjeldsen (2005), some of the substances left are still emitted as they leave the landfill. In the future, this impact is expected to drop since these substances are banned in new products, but the cooling agent substances that are replacing CFCs are not included, due to lack of data, and it is therefore not known if this impact is still going to be of importance in future environmental assessment of landfills. But in countries where electronic waste must be collected separately this should not be a concern, and this is a good reason to promote separate collection of electronic waste to remove this uncertainty about a potential impact. 


\subsection{Toxic impact categories}

Impact potentials on toxicity-related categories are also presented in Figure 1. Leachate controlling measures (bottom-liner and collection) lead to increased toxicity to the water ecosystem (from $0.007 \mathrm{PE}$ to $0.012 \mathrm{PE}$ per tonne waste). This is due to the fact that the leachate is treated at a wastewater plant, and the treated water is discharged into surface waters. There will though still be a minor amount of contaminants left in the treated water (e.g. copper and zinc) that will lead to an increased impact of eco-toxicity in water. The reason this impact is not as high in the not lined systems (L1G1 and L1G2) is that the leachate here will end in the groundwater resource and thereby will not be accredited to the surface water. As it can be seen from Figure 2, it is the unlined systems that cause the largest impact, which shows that the burdens are just shifted when controlling the leachate. The size in PE should not be compared directly since the methodology between the two impacts is quite different, but it gives a good picture of why it is necessary to collect the leachate. It is to be noted that the main contributor to spoiled groundwater resources is ammonia, and the contribution and fate of this substance should be further studied to establish its importance.

Eco-toxicity in soil is having such a small impact that it is not even noticeable on the figure, but has been kept in order to show that it was calculated. The same applies to human toxicity via air. The reason for the very small impact is that it is mainly caused by emissions associated with the combustion from the on-site vehicles; thus, once normalized with the yearly contribution for one person, this impact becomes very small.

Human toxicity via soil is where the largest contribution and also changes are calculated for the toxic impact categories. The main reason for this is that organic compounds (benzene, vinylchloride etc.), which are found to be the main contributing substances to the impact, are oxidized as soon as a retention time is introduced via a cover material. By collecting the gas and flaring or combusting it, the amount of substance being converted is further increased, showing the benefit of recovery over passive oxidation. That these substances have such a high impact is somewhat surprising, as it would have been expected that most of them would quickly degrade when being released to the atmosphere. By comparing the characterization factors with those of EDIP 2003 methodology (Hauschild and Potter, 2005) and USEtox methodology (Rosenbaum et al., 2008) it was found that the impact to soil from these substances is considerably lower in these methodologies. If lowering the impact from these substances the overall impact fell, but the trend for a large importance was the same. This does show that the uncertainty with regards to the toxic methodologies should be kept in mind, and that when the USEtox methodology for metals are finalized it may be better to move to this updated methodology for any future assessment.

For human toxicity via water there can be seen a growing trend as more measures are introduced, the only exception being when there are substitution taking place based on coal. The reason for the impact is mainly due to dioxin formation in the LFG combustion processes, as well as fugitive releases of mercury compounds. The reason for the savings is that coal power itself represents a huge mercury load to the atmosphere, and this offsets the emissions from the LFG leading to a net saving.

\subsection{Economic costs}

In order to link economic costs to environmental performance the net sum of the impacts potentials was plotted as a function of the costs for the landfill setup. The result of this is shown in Figure 3. The net impact potentials are calculated by associating all impacts with a weight of 
435

436

437

438

439

440

441

442

443

444

445

446

447

448

449

450

451

452

453

454

455

456

457

458

459

460

461

462

463

464

465

466

467

468

469

470

471

472

473

474

475

476

477

478

479

480 one, meaning all impacts are considered of similar importance. The choice of a uniform weight is taken to be neutral. The reader can compare the individual columns in Figure 1 with the costs in Table 6 to get a view of the disaggregated costs and impacts. Based on Figure 3 it is clear that the open dump is the cheapest but also the worst performing landfill as expected. It can be seen that by covering the dump the impact of the landfill can be drastically lowered for very little additional cost (40 versus 42 Euro). This is due to the drop in leachate formation due to evaporation in the top cover, as well as top cover oxidation of a large amount of the gas constituents. Furthermore, a cover would mean that the landfill is more esthetic, odor problems are minimized, blowing litter will be avoided and less vector intrusion (birds, rodents etc.) will take place. All of these impacts are not measured in a traditional LCA but would still be of relevance in the planning of a landfill. The installation of the leachate collection system is the most costly installation besides the base costs (10 Euro per $\mathrm{m}^{3}$ leachate), but it can be seen that there is still a large avoided impact from this, which is due to the drop in impact to SGR.

The treatment costs for the non-passive gas treatment systems are not varying very much (5763 Euro) and are mainly due to differences in cost and income for the combustion systems. The difference from the worst process in this category (L2G2) and the best (G4HC) is an impact of approximately $0.1 \mathrm{PE}$ while actually saving 5 Euro, due to the income from the energy paying for the gas collection and combustion equipment. The landfills substituting heat seems to be a better choice than electricity, which is due to the fact that the efficiency of the heat generation is remarkably higher. It has though to be kept in mind that this option is only viable if there is a customer to receive the generated heat. Electricity can on the other hand always be sold to the grid and is therefore an easier default option. In general the energy recovery options are a better option than the non-energy scenarios since the payment for the sold energy offsets the plant costs of the generators, and at the same time the substituted energy means that the environmental impact is considerably lower. This is only true as long as the studied landfill has a high methane production (f.x. from household waste), whereas a low-carbon landfill would most likely not generate enough methane to support energy production. The presented overall uncertainty in Table 6 indicates that there is in reality not any difference between the cost for the more advanced treatment technologies, as the uncertainty is as big as the largest difference between these technologies. There should therefore not be any reason for not going for the optimal treatment technology as long as the energy can be sold.

\subsection{Conclusions}

Overall, it can be observed that the efficiencies of gas and leachate collection systems are crucial parameters in the assessment, since a poor collection compromises the overall environmental performance. However, when good efficiencies are achieved, other circumstances might affect the assessment. With respect to landfill gas, the considered combustion treatment measures have demonstrated to generate emissions which are of particular concern for the toxicity-related impacts. Furthermore, contaminated leachate is expected to be generated in significant amounts long after the end of the collection period (70 years). As a consequence, a substantial potential impact on spoiled groundwater resource still exists in those landfills collecting leachate.

Since there is a linear correlation per tonne of waste in our calculations, between leachate generation and the amount of leachate substance generated, the uncertainty with regards to the leachate generation per tonne of waste will mean this uncertainty is reflected in the leachate substances and hence the overall impact of the landfill. But of even more importance is the geographical location of the landfill, as the precipitation rates vary considerably from region to 
481 region, and a landfill in an arid versus a humid region will mean a difference in orders of

482 magnitude for the potential leachate generation. Similarly, the landfill depth when the final cap is

483 placed will determine the surface area of the landfill, and hence the leachate generation rate. The

484 same is the case for the methane and LFG generation where there is a large variability in

485 generation rates depending on the composition of the landfilled waste. It is therefore important in

486 a study to have a good knowledge of the waste fractions entering the landfill. When for instance

487 doing an integrated waste study with different diversion rates it is crucial to make sure that this is 488 updated whenever the composition changes (if this is not done automatically by the model).

489 It is therefore very important when doing an LCA study for waste management to make sure 490 that the landfill being modeled is not just an average landfill, but that it actually represents the 491 state of technology present or intended for the system.

492

\section{Acknowledgements}

494 We would like to thank H.C. Willumsen (LFG Consult, Viborg, Denmark) for his comments to 495 our cost estimates for the landfill designs. Also a big thank to Gitte Lemming, DTU

496 Environment, on the help with the normalization reference for groundwater contamination. 


\section{References}

Bates, J., Haworth, A., 2001. Economic Evaluation of Emission Reductions of Methane in the Waste Sector in the EU - Bottom-up Analysis. Rep. No. Contract report for European commission, DG Environment, European commission.

Birgisdóttir, H., Bhander, G., Hauschild, M. Z., Christensen, T. H., 2007. Life cycle assessment of disposal of residues from municipal solid waste incineration: recycling of bottom ash in road construction or landfilling in Denmark evaluated in the ROAD-RES model. Waste management, 27(8), 75-84.

Börjesson, G., Samuelsson, J., Chanton, J., Adolfsson, R., Galle, B., Svensson, B.H., 2009. A national landfill methane budget for Swede based on field measurements, and a evaluation of IPCC models. Tellus - Series B - Chemical and Physical Meteorology 61, Issue 2, 424-435.

Chanton, J.P., Powelson, D.K., Green. R.B., 2009. Methane oxidation in landfill cover soils, is a 10\% default value reasonable? Journal of Environmental Quality 38, 654-663.

Christensen, T. H., Gentil, E., Boldrin, A., Larsen, A., Weidema, B., Hauschild, M., 2009. C balance, carbon dioxide emissions and global warming potentials. Waste Management \& Research, 26, 1-9.

Delaware Solid Waste Authority, 2006. Southern Solid Waste Management Center Facility Fact Sheet.. Delaware Solid Waste Authority. 2006.

Deipser, A., Poller, T., Stegmann, R., 1996. Emissions of volatile halogenated hydrocarbons from landfills. In: Christensen, T.H., Cossu, R., Stegmann, R. (Eds.), Landfilling of Waste: Biogas. Elsevier, London, UK

Danmarks Miljøundersøgelser \& Dansk Jordbrugsforskning, DMU \& DJF, 2003. Vandmiljøplan II: Slutevaluering (In Danish). Danmarks Miljøundersøgelser. Miljøstyrelsen, Copenhagen. Denmark

Ehrig, H.J., 1983. Quality and quantity of sanitary landfill leachate. Waste Management \& Research, 1, 53-68

Gebert, J., 2003. Development of a biofiltration system for the degradation of methane, odours and trace gases emitted from passively vented landfills. University of Hamburg - Institute of Soil Science, Hamburg, Germany \& German Federal Ministry for Education and Research.

Fruergaard, T., Ekvall, T. \& Astrup, T., 2009. Energy use and recovery in waste management and implications for accounting of greenhouse gases and global warming contributions. Waste Management \& Research, 27, 724-737.

Hansen, E., Olsen, S.I., Schmidt, A., Hauschild, M., Hjelmar, O., Bendtsen, N., Poulsen, T.S., Hansen, H.H., Christensen, K. (2004); Life cycle assessment of landfilled waste (in Danish). Environmental project no. 971, Danish Environmental Protection Agency, Copenhagen, Denmark

Hauschild, M., Potting, J., 2005. Spatial differentiation in life cycle impact assessment - the EDIP 2003 methodology. Guidelines from the Danish Environmental Protection Agency, Danish Environmental Protection Agency, Copenhagen, Denmark. 
Hauschild, M., Olsen, S. I., Hansen, E., Schmidt, A. 2008. Gone...but not away—addressing the problem of long-term impacts from landfills in LCA. The International Journal of Life Cycle Assessment, 13(7), 547-554.

Hogg, D., 2002. Costs for Municipal Waste management in the EU - Final report to DGE, European commission. European Commission, Eunomia Research \& Consulting Ltd.

Johannessen, L.M. 1999a. Guidance Note on Leachate Management for Municipal Solid Waste Landfills. Rep. No. 20962, The World Bank.

Johannessen, L.M., 1999b. Guidance Note on Recuperation of Landfill Gas from Municipal Solid Waste Landfills. Rep. No. 20962, The World Bank.

Kirkeby, J.T., Hansen, T.L., Birgisdóttir, H., Bhander, G.S., Hauschild, M.Z. \& Christensen, T.H., 2006. Environmental assessment of solid waste systems and technologies: EASEWASTE. Waste Management and Research, 24, 3-15.

Kirkeby,J.T., Birgisdóttir,H., Bhander,G.S., Hauschild,M.Z. \& Christensen,T.H. 2007. Modelling of environmental impacts of solid waste landfilling within the life cycle analysis program EASEWASTE. Waste Management, 27, 961-970.

Kjeldsen, P., Christophersen, M., 2001. Composition of leachate from old landfills in Denmark. Waste Management and Research 19, 249-256.

Lee, G.F., Jones, R.A., 1993. Groundwater pollution by municipal landfills: leachate composition, detection and water quality significance. In: Proceedings Sardinia1993, Fourth International Landfill Symposium. S. Margherita di Pula, Cagliari, Italy.

Mahieu, K., De Visscher, A., Vanrolleghen, P.A., Van Cleemput, O., 2005. Improved quantification of methane oxidation in landfill soil covers by numerical modeling of stable isotope fractionation. In: Proceedings Sardinia 2005, Tenth Waste Management and Landfill Symposium, October 3-7. S. Margherita di Pula, Cagliari, Italy.

Manfredi, S., Christensen, T.H., 2009. Environmental assessment of solid waste landfilling technologies by means of LCA-modeling. Waste Management, 29, 32-43.

National Society for Clean Air and Environment, NSCA, 2002. Comparison of emissions from waste management options. Brighton BN2 9QA, UK.

Purdy, S., Shedden, R., 2005. "Cost/benefit analysis for the development of a landfill expansion module in California." CISA, Environmental Sanitary Engineering Centre.

Reinhart, D.R., Grosh, C.J., 1998. Analysis of Florida MSW Landfill Leachate Quality. University of Central Florida: Civil and Environmental Engineering Department, Florida Center for Solid and Hazardous Waste Management, Report no. 97-3.

Rettenberger, G., 2005. Landfill Gas Characterization Over Time - the 9-phase model. In: Proceedings Sardinia 2005, Tenth International Waste Management and Landfill Symposium, S. Margherita di Pula, Cagliari, Italy.

Rettenberger, G., Stegmann, R., 1996. Landfill gas components. In: Christensen, T.H., Cossu, R., Stegmann, R. (Eds.), Landfilling of Waste: Biogas. Elsevier, London, UK. 
Robinson, H.D., Knox K., 2003. Updating the landfill leachate Pollution Inventory reporting tool. R\&D Technical Report No PI-496/TR(2). Environment Agency, United Kingdom.

Rosenbaum, R.K., Bachmann, T.M., Gold, L.S., Huijbregts, M.A., Jolliet, O., Juraske, R., Koehler, A., Larsen, H.F., MacLeod, M., Margni, M., McKone, T.E., Payet, J., Schuhmacher, M., Meent, D., Hauschild, M.Z., 2008. USEtox-the UNEP-SETAC toxicity model: recommended characterisation factors for human toxicity and freshwater ecotoxicity in life cycle impact assessment, The International Journal of Life Cycle Assessment, 13, 532-546.

Scheutz, C. 2002. Attenuation of methane and trace organics in landfill soil covers. Ph.D. Thesis, Department of Environmental Engineering, Technical University of Denmark, Kgs. Lyngby, Denmark.

Scheutz, C., Mosbæk, H., Kjeldsen, P., 2004. Attenuation of methane and volatile organic compounds in landfill soil covers. Journal of Environmental Quality 33, 61-71.

Scheutz, C., Kjeldsen, P., 2005. Biodegradation of trace gases in simulated landfill soil cover. Environmental Science and Technology 37, 5143-5149.

Stranddorf, H.K., Hoffmann L., Schmidt, A., 2005. Impact Categories, normalization and weighting in LCA - Update on selected EDIP97-data. Environmental news No. 78. Copenhagen, Denmark: Danish Environmental Protection Agency, Danish Ministry of the Environment; 2005

Streese, J., Damman, B., Stegmann, R., 2001. Reduction of methane and trace gas emissions from former landfills in biofilters. In: Proceedings Sardinia 2001, Eight International Waste Management and Landfill Symposium, S. Margherita di Pula, Cagliari, Italy.

U.S. EPA., 1989. Assessment of Needed Publicly Owned Wastewater Treatment Facilities in the United States 1988 Needs Survey Report to Congress. EPA 430/09-89-001, U.S. Environmental Protection Agency.

U.S. EPA., 1992. Documentation for the EPA Computer Program for Development of Local Discharge Limitations Under The Pretreatment Program. US EPA. Office of Water (EN-336). 21W-4003.

U.S. EPA., 1995. Emission Factor Documentation for AP-42 Section 2.4, Municipal Solid Waste Landfills. U.S. Environmental Protection Agency, Office of Air Quality Planning and Standards, Office of Air and Radiation

U.S. EPA., 2000. Emission Factor Documentation for AP-42 Section 3.1, Stationary Internal Combustion Sources. U.S. Environmental Protection Agency, Office of Air Quality Planning and Standards, Office of Air and Radiation

U.S. EPA., 2008. Background Information Document for Updating AP42 Section 2.4 for Estimating Emissions from Municipal Solid Waste Landfills. U.S. Environmental Protection Agency, Office of Research and Development. EPA/600/R-08-116

Wenzel, H., Hauschild, M., Alting, L., 1997. Environmental Assessment of Products. Volume 1: Methodology, tools and case studies in product development. Published by Chapman \& Hall, 2-6 Boundary Row, London, UK

World Health Organization, WHO, 2006. Guidelines for Drinking-Water Quality - First Addendum to Third Edition, vol. 1. WHO Press, 20 Avenue Appia, 1211 Geneva 27, Switzerland, ISBN 9241546964. 

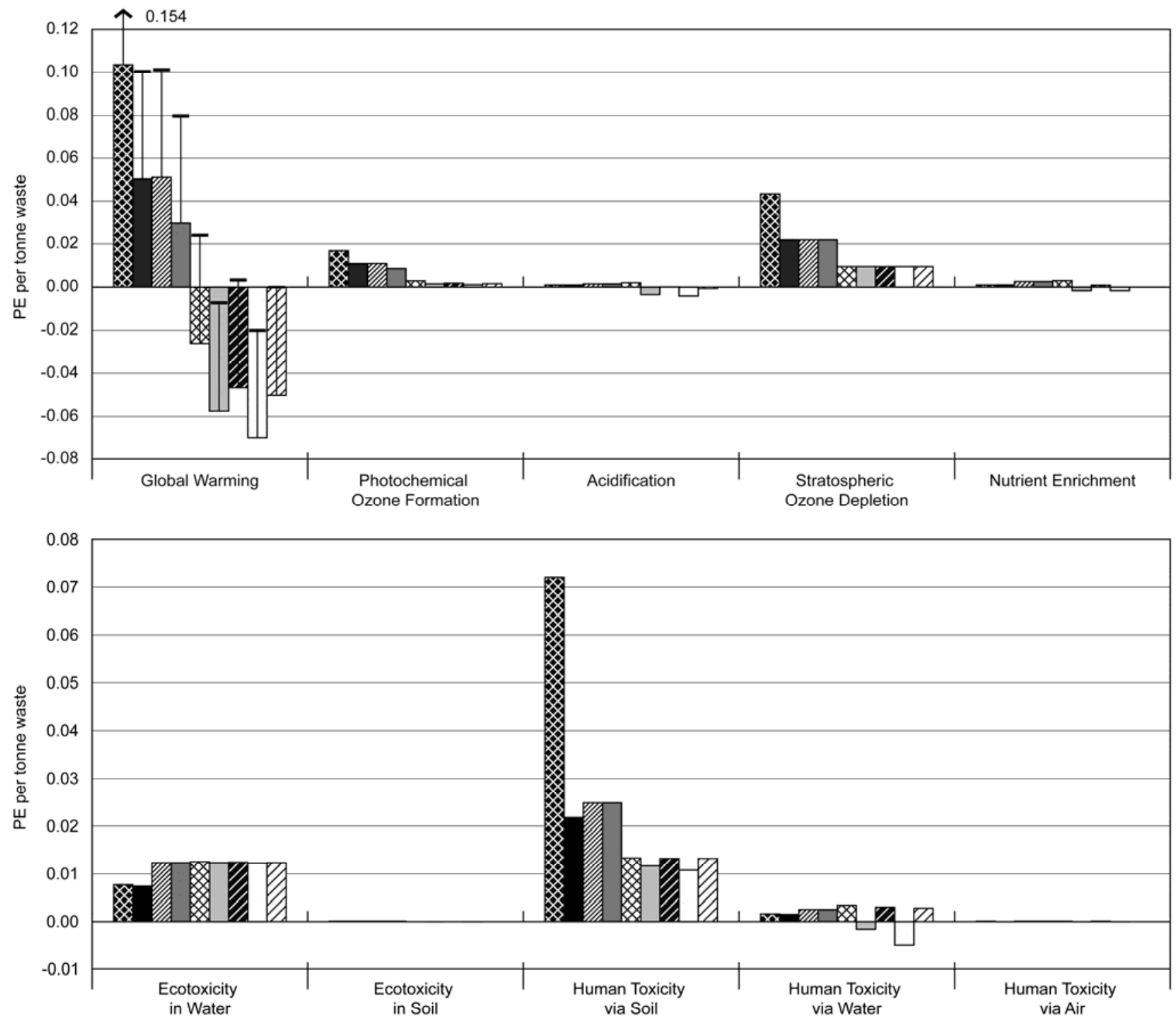

$\begin{array}{lll}\otimes \text { L1G1 } & \square \text { L2G3A - biofilter } & \mathbb{Z} \text { G4EN - Electricity Natural Gas } \\ \text { L1G2 } & \text { L2G3A - Flare } & \square \text { G4HC - Heat coal based } \\ \text { L2G2 } & \square \text { G4EC - Electricity Coal } & \square \text { G4HN - Heat Natural Gas } \\ & & T \text { No carbon sequestration }\end{array}$

Figure 1 Environmental impacts for the nine landfill scenarios. Values given in person equivalent (PE) per tonne wet waste landfilled. 


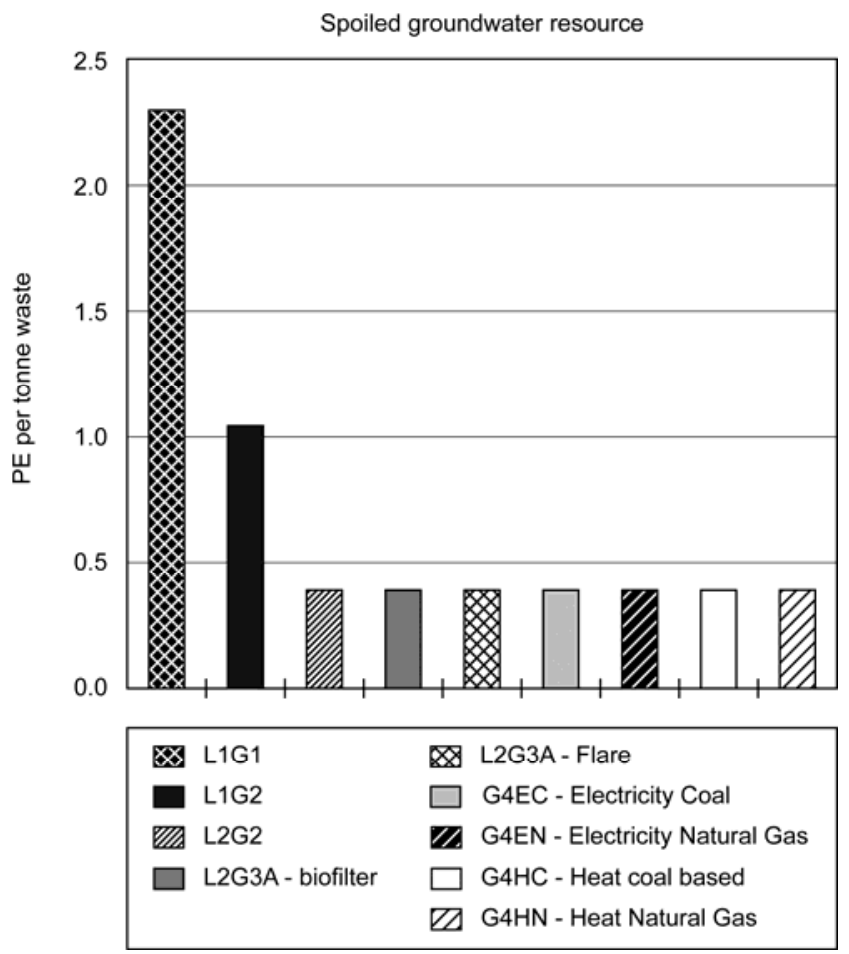

Figure 2 Spoiled groundwater resources for the nine landfills. Values given in person equivalent (PE) per tonne wet waste landfilled.

629

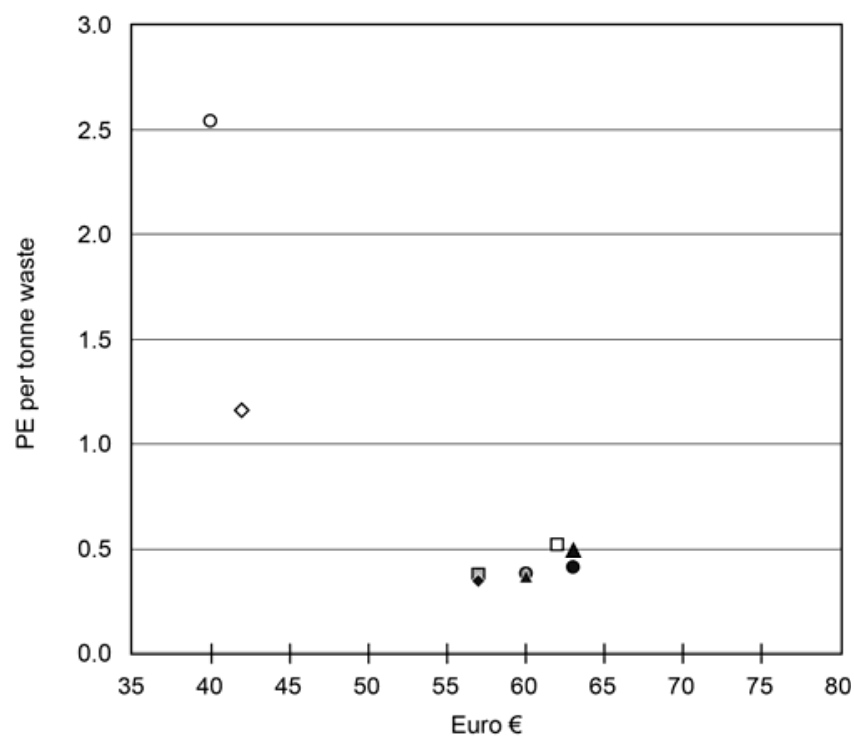

\begin{tabular}{|lll}
\hline$\circ$ L1G1 & $\Delta$ L2G3A- biofilter & ○ G4EN - Electricity Natural Gas \\
$\diamond$ L1G2 & $\bullet$ L2G3A-Flare & $\bullet$ G4HC - Heat coal based \\
口 L2G2 & ॥ G4EC - Electricity Coal & $\square$ G4HN - Heat Natural Gas
\end{tabular}

Figure 3 All potential impacts (standard, toxic and SGWR)in PE per tonne waste as a function of the costs of the treatment type in Euro. The error bars show the uncertainty of the individual treatment technologies as presented in Table 6. 


\section{Tables}

Table 1 Potential impact categories included in EASEWASTE (after Kirkeby et al., 2006). Normalization references after Stranddorf et al. (2005).

\begin{tabular}{|c|c|c|c|c|}
\hline $\begin{array}{l}\text { Potential Impact } \\
\text { Category }\end{array}$ & Acronym & Unit & $\begin{array}{l}\text { Physical } \\
\text { basis }\end{array}$ & $\begin{array}{l}\text { Normalization reference } \\
\text { EU-15 }\end{array}$ \\
\hline $\begin{array}{l}\text { Global Warming, } 100 \\
\text { years }\end{array}$ & GW & kg CO ${ }_{2}$-eq. /person/yr & Global & 8700 \\
\hline $\begin{array}{l}\text { Photochemical Ozone } \\
\text { Formation }\end{array}$ & POF & $\mathrm{kg} \mathrm{C}_{2} \mathrm{H}_{4}$-eq. /person/yr & Regional & 25 \\
\hline Ozone Depletion & OD & kg CFC-11-eq./person/yr & Global & 0.103 \\
\hline Acidification & $\mathrm{AC}$ & $\mathrm{kg} \mathrm{SO}_{2}$-eq. /person/yr & Regional & 74 \\
\hline Nutrient Enrichment & $\mathrm{NE}$ & $\mathrm{kg} \mathrm{NO}_{3}{ }^{-}$eq. /person/yr & Regional & 119 \\
\hline Human Toxicity, soil & HTs & $\mathrm{m}^{3}$ soil /person/yr & Regional & 157 \\
\hline Human Toxicity, water & HTw & $\mathrm{m}^{3}$ water /person/yr & Regional & 179000 \\
\hline Human Toxicity, air & HTa & $\mathrm{m}^{3}$ air /person/yr & Regional & 2090000000 \\
\hline Ecotoxicity, soil & ETs & $\mathrm{m}^{3}$ soil /person/yr & Regional & 964000 \\
\hline $\begin{array}{l}\text { Ecotoxicity, water } \\
\text { chronic }\end{array}$ & ETwc & $\mathrm{m}^{3}$ water /person/yr & Regional & 352000 \\
\hline $\begin{array}{l}\text { Spoiled Groundwater } \\
\text { Resources }\end{array}$ & SGWR & $\mathrm{m}^{3}$ water /person/yr & Local & $2900^{a}$ \\
\hline
\end{tabular}


Table 2 Gas concentrations in the landfill gas and oxidation in the top cover for the conventional landfill. Stegmann (1996), Scheutz et al. (2004), Scheutz and Kjeldsen (2005).

\begin{tabular}{|c|c|c|c|c|c|c|c|c|}
\hline & $\begin{array}{l}\text { Period } 1 \\
\text { (2yr) }\end{array}$ & & $\begin{array}{l}\text { Period } 2 \\
\text { (3yr) }\end{array}$ & & $\begin{array}{l}\text { Period } 3 \\
\text { (35yr) }\end{array}$ & & $\begin{array}{l}\text { Period } 4 \\
\text { (60yr) }\end{array}$ & \\
\hline substances & Composition & $\begin{array}{l}\text { Ox. } \\
\text { (\%) }\end{array}$ & Composition & $\begin{array}{l}\text { Ox. } \\
(\%)\end{array}$ & Composition & $\begin{array}{l}\text { Ox. } \\
(\%)\end{array}$ & Composition & $\begin{array}{l}\text { Ox. } \\
(\%)\end{array}$ \\
\hline Methane $\left(\mathrm{CH}_{4}\right)$ & $25 \%$ & & $40 \%$ & & $60 \%$ & & $5 \%$ & \\
\hline \multirow[t]{2}{*}{ Carbon dioxide $\left(\mathrm{CO}_{2}\right)$} & $70 \%$ & & $60 \%$ & & $40 \%$ & & $30 \%$ & \\
\hline & $\begin{array}{l}(\mathrm{g} / \mathrm{nm} 3 \\
\mathrm{LFG})\end{array}$ & & (g/nm3 LFG) & & $\begin{array}{l}(\mathrm{g} / \mathrm{nm} 3 \\
\mathrm{LFG})\end{array}$ & & $\begin{array}{l}(\mathrm{g} / \mathrm{nm} 3 \\
\mathrm{LFG})\end{array}$ & \\
\hline Benzene & 0.007 & 0 & 0.007 & 26 & 0.007 & 26 & 0.007 & 50 \\
\hline Carbon Monoxide & $1 \mathrm{E}-5$ & 0 & $1 \mathrm{E}-5$ & 20 & $1 \mathrm{E}-5$ & 20 & $1 \mathrm{E}-5$ & 40 \\
\hline Carbon tetrachloride & $3 E-5$ & 0 & $3 \mathrm{E}-5$ & 0 & $3 \mathrm{E}-5$ & 0 & $3 E-5$ & 0 \\
\hline CFC 11 & 0.01 & 0 & 0.01 & 90 & 0.01 & 90 & 0.01 & 90 \\
\hline CFC12 & 0.02 & 0 & 0.02 & 30 & 0.02 & 30 & 0.02 & 30 \\
\hline Chlorobenzene & 0.002 & 0 & 0.0 .002 & 0 & 0.002 & 0 & 0.002 & 0 \\
\hline Chloroform & 0.005 & 0 & 0.005 & 0 & 0.005 & 0 & 0.005 & 0 \\
\hline Ethylbenzene & 0.05 & 0 & 0.05 & 26 & 0.05 & 26 & 0.05 & 50 \\
\hline Ethylene dichloride & 0.05 & 0 & 0.05 & 0 & 0.0 .05 & 0 & 0.05 & 0 \\
\hline HCFC 21 & 0.012 & 0 & 0.012 & 60 & 0.012 & 60 & 0.012 & 60 \\
\hline HCFC 22 & 0.013 & 0 & 0.013 & 40 & 0.013 & 40 & 0.013 & 40 \\
\hline Hydrogen chloride & 0.006 & 0 & 0.006 & 0 & 0.006 & 0 & 0.006 & 0 \\
\hline Hydrogen fluoride & 0.002 & 0 & 0.002 & 0 & 0.002 & 0 & 0.002 & 0 \\
\hline Hydrogen sulphide & $7 E-5$ & 0 & $7 \mathrm{E}-5$ & 20 & $7 \mathrm{E}-5$ & 20 & $7 \mathrm{E}-5$ & 40 \\
\hline Methylene chloride & 0.05 & 0 & 0.05 & 40 & 0.05 & 40 & 0.05 & 40 \\
\hline Mercury & $3.5 \mathrm{E}-6$ & 0 & $3.5 \mathrm{E}-6$ & 0 & $3.5 \mathrm{E}-6$ & 0 & $3.5 \mathrm{E}-6$ & 0 \\
\hline Tetrachloroethene & 0.027 & 0 & 0.027 & 40 & 0.027 & 40 & 0.027 & 40 \\
\hline Toluene & 0.16 & 0 & 0.16 & 60 & 0.16 & 60 & 0.16 & 60 \\
\hline Trichloroethene & 0.016 & 0 & 0.016 & 40 & 0.016 & 40 & 0.016 & 40 \\
\hline Vinyl chloride & 0.01 & 0 & 0.01 & 90 & 0.01 & 90 & 0.01 & 90 \\
\hline VOCs & 0.23 & 0 & 0.23 & 60 & 0.23 & 60 & 0.23 & 80 \\
\hline Xylenes & 0.06 & 0 & 0.06 & 30 & 0.06 & 30 & 0.06 & 30 \\
\hline "The open dump land & $\begin{array}{l}\text { l does not have } \\
\text { methane oxidat }\end{array}$ & On En & $\begin{array}{l}\text { er, hence no o } \\
\text { encies for the }\end{array}$ & 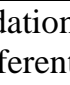 & $\begin{array}{l}\text { of gas constit } \\
\text { landfills see }\end{array}$ & $\begin{array}{l}\text { its is } \\
\text { e } 5 \text {. }\end{array}$ & sumed to occ & r. For \\
\hline
\end{tabular}


685

Table 3 Leachate data for the conventional landfill for the four time periods ( $\mathrm{g} / \mathrm{m}^{3}$ leachate). Based on Ehrig (1983), Kjeldsen and Christophersen (2001), Lee and Jones (1993), Reinhart et al. (1998). Removal efficiencies are based on Knox et al. (2003), U.S. EPA (1989 and 1992)

\begin{tabular}{|c|c|c|c|c|c|}
\hline & $\begin{array}{l}\text { Period } 1 \\
\text { (2 years) }\end{array}$ & $\begin{array}{l}\text { Period } 2 \\
\text { (8 years) }\end{array}$ & $\begin{array}{l}\text { Period } 3 \\
\text { (30 years) }\end{array}$ & $\begin{array}{l}\text { Period } 4 \\
\text { (60 years) }\end{array}$ & $\begin{array}{r}\text { Removal in WWTE688) } \\
689\end{array}$ \\
\hline \multicolumn{6}{|c|}{ (- } \\
\hline TSS & 60 & 60 & 60 & 60 & 96 \\
\hline BOD & 13000 & 8000 & 800 & 30 & 97 \\
\hline COD & 15000 & 12000 & 3000 & 200 & 80 \\
\hline $\mathrm{NH}_{3}$ & 1000 & 700 & 500 & 400 & 98 \\
\hline $\mathrm{PO}_{4}$ & 14 & 14 & 14 & 14 & 22 \\
\hline Calcium & 1000 & 1000 & 1000 & 1000 & 85 \\
\hline Chloride & 2500 & 2000 & 1500 & 980 & 85 \\
\hline Magnesium & 300 & 300 & 300 & 300 & 85 \\
\hline Sodium & 700 & 500 & 400 & 200 & 85 \\
\hline \multicolumn{6}{|l|}{ Trace Organics } \\
\hline Benzene & 0.0065 & 0.0065 & 0.0065 & 0.0065 & 99 \\
\hline Chloroform & 0.0003 & 0.0003 & 0.0003 & 0.0003 & 99 \\
\hline Ethylbenzene & 0.02 & 0.02 & 0.02 & 0.02 & 80 \\
\hline Ethylene dichloride & 0.05 & 0.05 & 0.014 & 0.014 & 70 \\
\hline Methylene chloride & 0.03 & 0.015 & 0.008 & 0.004 & 70 \\
\hline Tetrachloroethene & 0.01 & 0.01 & 0.01 & 0.01 & 70 \\
\hline Toluene & 0.16 & 0.16 & 0.02 & 0.02 & 80 \\
\hline Trichloroethene & 0.005 & 0.005 & 0.007 & 0.007 & 70 \\
\hline Vinyl chloride & 0.05 & 0.05 & 0.04 & 0.04 & 70 \\
\hline Xylenes & 0.05 & 0.05 & 0.05 & 0.05 & 60 \\
\hline \multicolumn{6}{|l|}{ Metals } \\
\hline Arsenic & 0.03 & 0.025 & 0.02 & 0.02 & 70 \\
\hline Barium & 0.5 & 0.3 & 0.2 & 0.16 & 85 \\
\hline Cadmium & 0.012 & 0.01 & 0.008 & 0.006 & 85 \\
\hline Chromium & 0.07 & 0.06 & 0.05 & 0.04 & 30 \\
\hline Copper & 0.12 & 0.1 & 0.1 & 0.07 & 50 \\
\hline Lead & 0.06 & 0.04 & 0.02 & 0.005 & 85 \\
\hline Mercury & 0.0004 & 0.0003 & 0.0002 & 0.0002 & 85 \\
\hline Nickel & 0.07 & 0.06 & 0.05 & 0.04 & 20 \\
\hline Selenium & 0.01 & 0.008 & 0.006 & 0.006 & 85 \\
\hline Silver & 0.08 & 0.07 & 0.03 & 0.01 & 85 \\
\hline Zinc & 4 & 2.2 & 1.5 & 0.7 & 70 \\
\hline
\end{tabular}


704 Table 4 The 7 scenarios with the technical measures (L \& G) applied in each scenario.

\begin{tabular}{lcl}
\hline Landfill Type & $\begin{array}{c}\text { Technical } \\
\text { Measure }\end{array}$ & Description \\
\hline Dump & L1 + G1 & Open, no treatment \\
$\begin{array}{l}\text { Open Dump } \\
\text { Covered Dump }\end{array}$ & L1 + G2 & Covered with soil to allow for top cover oxidation.
\end{tabular}

Simple conventional

Simple

Biofilter

Flaring

Energy recovery landfill

Energy recovery for electricity production

Energy recovery for heat production.
L2 + G2 Leachate is collected and sent to treatment, no gas mitigation besides top cover oxidation

L2 + G3A Leachate is collected and sent to treatment, gas collection and treatment with biofilter

L2 + G3B Leachate is collected and sent to treatment, gas collection and combustion in flares.

L2+G4E Leachate is collected and sent to treatment. Gas is collected and sent to a combustion engine for electricity production. Substituting electricity based on combustion of coal or natural gas

$\mathrm{L} 2+\mathrm{G} 4 \mathrm{H} \quad$ Leachate is collected and sent to treatment. Gas is collected and sent to a boiler for heat production. Substituting heat based on combustion of coal or natural gas. 
Table 5 Key parameters describing the defined conventional landfill technologies in terms of measures for leachate and gas control. For each cell per period is defined the number of years, and the amount per period

\begin{tabular}{|c|c|c|c|c|}
\hline & Time period 1 & Time period 2 & Time period 3 & Time period 4 \\
\hline \multicolumn{5}{|l|}{ The dump (L1, G1) } \\
\hline Gas generated (\% of gas potential) & $2 \mathrm{y}: 2 \%$ & 3y: $8 \%$ & 35y: 70\% & $60 y: 16 \%$ \\
\hline Gas collected (\% of generated) & None & None & None & None \\
\hline $\begin{array}{l}\text { Gas oxidized by top cover } \\
\text { (\% of uncollected) }\end{array}$ & None & None & None & None \\
\hline Leachate generated $(\mathrm{mm} / \mathrm{y})$ & $2 \mathrm{y}: 500$ & $8 \mathrm{y}: 500$ & 40y: 450 & $50 y: 450$ \\
\hline Leachate collected (\% of generated) & None & None & None & None \\
\hline Leachate entering groundwater (\% of generated) & $2 \mathrm{y}: 100 \%$ & $8 y: 100 \%$ & $40 \mathrm{y}: 100 \%$ & 50y: $100 \%$ \\
\hline \multicolumn{5}{|l|}{ The covered dump (L1, G2) } \\
\hline Gas generated (\% of gas potential) & $2 \mathrm{y}: 2 \%$ & 3y: $8 \%$ & $35 y: 70 \%$ & $60 y: 16 \%$ \\
\hline Gas collected (\% of generated) & None & None & None & None \\
\hline $\begin{array}{l}\text { Gas oxidized by top cover } \\
\text { (\% of uncollected) }\end{array}$ & $2 \mathrm{y}: 0 \%$ & 3y: 35\% & $35 y: 35 \%$ & 60y: $80 \%$ \\
\hline Leachate generated $(\mathrm{mm} / \mathrm{y})$ & $2 \mathrm{y}: 500 \mathrm{~mm} / \mathrm{y}$ & 8y. 250 mm/y & $30 \mathrm{y}: 200 \mathrm{~mm} / \mathrm{y}$ & 60y: $180 \mathrm{~mm} / \mathrm{y}$ \\
\hline Leachate collected (\% of generated) & None & None & None & None \\
\hline Leachate entering groundwater ( $\%$ of generated) & $2 \mathrm{y}: 100 \%$ & $8 y: 100 \%$ & $40 \mathrm{y}: 100 \%$ & $50 \mathrm{y}: 100 \%$ \\
\hline \multicolumn{5}{|c|}{ The simple conventional landfill ( $L 2$ and, G2, G3A or G3B) } \\
\hline Gas generated (\% of gas potential) & $2 \mathrm{y}: 2 \%$ & 3y: $8 \%$ & 35y: 70\% & $60 y: 16 \%$ \\
\hline Gas collected (\% of generated) & $2 \mathrm{y}: 0 \%$ & 3y: 75\% & 35y: 75\% & 60y: $0 \%$ \\
\hline Gas management & None & Flared/filter & Flare/filter & None \\
\hline $\begin{array}{l}\text { Gas oxidized by top cover } \\
\text { (\% of uncollected) }\end{array}$ & $2 \mathrm{y}: 0 \%$ & 3y: $80 \%$ & 35y: $80 \%$ & 60y: $70 \%$ \\
\hline Leachate generated $(\mathrm{mm} / \mathrm{y})$ & $2 \mathrm{y}: 500 \mathrm{~mm} / \mathrm{y}$ & 8y. $250 \mathrm{~mm} / \mathrm{y}$ & 30y: $200 \mathrm{~mm} / \mathrm{y}$ & $60 \mathrm{y}: 180 \mathrm{~mm} / \mathrm{y}$ \\
\hline Leachate collected (\% of generated) & 20y: $95 \%$ & 20y: $80 \%$ & 30y: $60 \%$ & 30y: $0 \%$ \\
\hline Leachate entering groundwater (\% of generated) & $20 \mathrm{y}: 5 \%$ & $20 y: 20 \%$ & 30y: $40 \%$ & 30y: $100 \%$ \\
\hline \multicolumn{5}{|l|}{ The energy-recovery conventional landfill (L2, G4) } \\
\hline Gas generated (\% of gas potential) & $2 \mathrm{y}: 2 \%$ & 3y: $8 \%$ & 35y: 70\% & $60 y: 16 \%$ \\
\hline Gas collected (\% of generated) & $2 \mathrm{y}: 0 \%$ & 3y: 75\% & 35y: 75\% & 60y: $0 \%$ \\
\hline Gas management & None & Flared & Elec/CHP & None \\
\hline $\begin{array}{l}\text { Gas oxidized by top cover } \\
\text { (\% of uncollected) }\end{array}$ & $2 \mathrm{y}: 0 \%$ & 3y: $80 \%$ & 35y: $80 \%$ & $60 y: 80 \%$ \\
\hline Leachate generated $(\mathrm{mm} / \mathrm{y})$ & $2 y: 500 \mathrm{~mm} / \mathrm{y}$ & 8y. $250 \mathrm{~mm} / \mathrm{y}$ & 30y: $200 \mathrm{~mm} / \mathrm{y}$ & $60 \mathrm{y}: 180 \mathrm{~mm} / \mathrm{y}$ \\
\hline Leachate collected (\% of generated) & $20 y: 95 \%$ & $20 \mathrm{y}: 80 \%$ & $30 y: 60 \%$ & $30 y: 0 \%$ \\
\hline Leachate entering groundwater (\% of generated) & $20 y: 5 \%$ & $20 y: 20 \%$ & 30y: $40 \%$ & 30y: 100\% \\
\hline
\end{tabular}


745 Table 6: Typical unit costs for technical measures included in the seven landfill configurations.

\begin{tabular}{|c|c|c|c|c|c|c|c|c|c|}
\hline Configuration & Unit & $\begin{array}{l}\text { G1 } \\
+ \\
\text { L1 }\end{array}$ & $\begin{array}{l}\mathrm{G} 2 \\
+ \\
\mathrm{L} 1\end{array}$ & $\begin{array}{l}\mathrm{G} 2 \\
+ \\
\mathrm{L} 2\end{array}$ & $\begin{array}{l}\text { G3A } \\
+ \\
\text { L2 }\end{array}$ & $\begin{array}{l}\text { G3B } \\
+ \\
\text { L2 }\end{array}$ & $\begin{array}{c}\text { G4EN/G4EC } \\
+ \\
\text { L2 }\end{array}$ & $\begin{array}{c}\text { G4HN/G4HC } \\
+ \\
\text { L2 }\end{array}$ & Uncertainty \\
\hline Baseline cost & $€ /$ tonne & 40 & 40 & 40 & 40 & 40 & 40 & 40 & \\
\hline Simple top cover & $€ /$ tonne & & 2 & & & & & & \\
\hline Top cover & $€ /$ tonne & & & 3 & 3 & 3 & 3 & 3 & \pm 1 \\
\hline Bottom liner & $€ /$ tonne & & & 4 & 4 & 4 & 4 & 4 & \pm 1 \\
\hline Leachate collection $^{\text {a }}$ & $€ /$ tonne & & & 2.5 & 2.5 & 2.5 & 2.5 & 2.5 & \pm 0.5 \\
\hline Leachate treatment & $€ /$ tonne & & & 11.2 & 11.2 & 11.2 & 11.2 & 11.2 & \pm 2 \\
\hline Gas collection $^{\mathrm{b}}$ & $€ /$ tonne & & & & 1 & 1 & 1 & 1 & \pm 0.01 \\
\hline Biofilter & $€ /$ tonne & & & & 0.1 & & & & \\
\hline Flare & $€ /$ tonne & & & & & 0.15 & & & \\
\hline Electricity plant & $€ /$ tonne & & & & & & 2 & & \pm 0.5 \\
\hline Heat plant & $€ /$ tonne & & & & & & & 1.0 & \pm 0.5 \\
\hline Electricity sold & $€ /$ tonne & & & & & & 5.2 & & \\
\hline District heating sold ${ }^{\mathrm{c}}$ & $€ /$ tonne & & & & & & & 6.9 & \\
\hline Total cost & $€ /$ tonne & 40 & 42 & 62 & 63 & 63 & 60 & 57 & \\
\hline Accumulated uncertainty & $€ /$ tonne & 0 & 0 & \pm 4.5 & \pm 5.6 & \pm 5.6 & \pm 6.1 & \pm 6.1 & \\
\hline
\end{tabular}

$746 \quad{ }^{\mathrm{a}} 1.12 \mathrm{~m}^{3}$ leachate per tonne waste.

$747 \quad{ }^{\mathrm{b}}$ LFG collection and treatment based on $100 \mathrm{~m}^{3}$

$748 \quad{ }^{\mathrm{c}} 56 \mathrm{~m}^{3}$ methane recovered for energy generation

749

750 